\title{
AIDS and its representation in the works of William S. Burroughs
}

\author{
Riccardo Gramantieri ${ }^{1}$
}

Accepted: 11 October 2021 / Published online: 19 November 2021

(c) Akadémiai Kiadó, Budapest, Hungary 2021

\begin{abstract}
In 1983, when the discovery of AIDS was publicly disclosed, many readers and admirers of William S. Burroughs pointed out how he had described the disease in his work. AIDS is very similar to the scarlet fever of Cities of the Red Night as reported by Burroughs (Cities of the red night, Picador, London 1981). Those who spoke of prophecy highlighted that the B-23 virus Burroughs described originated in Africa and is sexually transmitted, like HIV. This led to the idea that Burroughs had anticipated the spread of the virus. Burroughs played on this coincidence and commented that it is part of a writer's job to "shape" reality, but there are significant differences between the characteristics of the two viruses. In the first decades of the AIDS epidemic, there were alternative theories and disputes concerning the official aetiology at the same time that there was, as Burroughs represents, diffidence towards government healthcare systems. Many other plagues have been described in American fiction, and Burroughs might have invented his B-23 virus starting from these earlier examples. Thus, Burroughs's viruses, rather than foreshadowing the physical symptoms of AIDS, foreshadow the pseudo-scientific theories, thoughts and beliefs arising from the spread of the disease.
\end{abstract}

Keywords AIDS · William S. Burroughs · Conspiracy theory

RW: When I heard about it and how it is transmitted and how devious a disease it is, I immediately thought of your theories about viruses.

WB: Well, of course. I think some of my theories are correct.

RW: You were foreseeing the AIDS virus.

WB: Well, I should hope so. That's what writers are supposed to do (Burroughs, 1985, p. 619).

The Covid-19 pandemic has brought out many pseudoscientific theories and conspiracy hypotheses related to the birth of the disease, its spread, and responses to it.

Riccardo Gramantieri

grama@racine.ra.it

1 Independent scholar, Ravenna, Italy 
The emergence of theories that are at odds with the dominant view reflect a need for answers that generate a sense of safety. The spread of conspiracy theories certainly predates Covid-19: it happened with 9/11 and before that with AIDS. In the 1980s, there were scientists who denied the existence of the HIV virus and saw AIDS as a syndrome due to a general condition of the patient's body. William S. Burroughs chose another approach, imagining the virus as a way of the government to control the population.

Burroughs had been the writer-symbol of the beat generation and of the counterculture and had inspired many science fiction novels of the 1960s and 1970s. Burroughs - as a former drug addict who was subject to periodical relapses to addiction, and as a gay man-was in the two most at-risk groups. Although he was highly esteemed in the area of counterculture, literature and music, he was uninfluential within the gay community. He was old and misogynous, could not stand camp, and lived a relatively isolated life in Kansas, after having spent half his life in Tangier, Paris, London, and finally New York, where he relapsed into heroin. All of his literature focused on control, by both the government and corporations-hence, it is not surprising that his work concentrated on the conspiracy theory which, inevitably, started to pop up when the virus began to spread.

A few decades earlier, Burroughs had already described a virus the symptoms of which were similar to Kaposi's sarcoma, a condition that in those years was often diagnosed during the phase that preceded full-blown AIDS and which manifests itself with the formation of pink or purple skin spots or growths. During the 1980s, he revisited that topic and explicitly connected it to the recently discovered syndrome. During several interviews, he also expressed the idea that the AIDS virus was a governmental method for controlling certain groups of the population. In his prayer on Thanksgiving Day, in which Burroughs was sarcastically thankful about all the problems existing in the United States, he also added "Thanks for laboratory AIDS" (Burroughs, 1989, p. 7), thus giving substance to a rumour that was already widespread that the virus was an artificial product. It was not an isolated view. Scientific knowledge was also providing ambiguous answers to the problem. For about 10 years, Peter Duesberg and other researchers spread the idea that AIDS was not caused by a specific virus (HIV) but rather by a weakening of the body associated with high-risk behaviour. Burroughs's belief was in some ways opposite to Duesberg's belief: the virologist believed that it was exposure to certain substances that caused mmunodeficiency; Burroughs, on the other hand, who belonged precisely to the group of people who engaged in behaviours considered dangerous by Duesberg (drug addiction, sexual promiscuity), believed that the HIV virus played a role as a cause of AIDS but imagined it to be a bacteriological weapon. Burroughs represents the position that the virus is not what it seems to be (a product of nature spread across the world starting from a "patient zero" in Africa) but that it is an artificial virus spread with the purpose of distinguishing a segment of population featuring given behaviours.

In reality, HIV is the result of multiple cross-species transmissions of simian immunodeficiency viruses naturally infecting African chimps (Hahn \& Sharp, 2011). It started in 1979, when a few inexplicable deaths were reported (Gilman, 1988). However, it was not until 1981 that people started talking about a new 
disease. Between October 1980 and May 1981, five young, previously healthy gay men were treated in Los Angeles for Pneumocystis carinii pneumonia. It is a type of pneumonia that usually affects people with severely weakened immune systems. In June 1981, the Center for Disease Control and Prevention (CDC) published an article in their weekly newsletter about the five men and their cases, and information about the new disease spread quickly in the medical community (Beck-Sague, Beck). In 1983, the French virologist Luc Montagnier isolated a virus from an AIDS patient, which was called LAV (lymphadenopathy-associated virus); the following year, the American virologist Robert Gallo announced the discovery of a similar virus, the HTLV-III. Aside from the dispute on the priority of the discovery, in 1987 the International Committee on Taxonomy of Viruses recognised the cause of AIDS to be a virus called Human Immunodeficiency Virus (HIV).

The causal role of the HIV virus has been fully accepted (Kurth), but a few eminent scientists have challenged the discoveries made by Montagnier and Gallo. Within ten years of the discovery of AIDS, "virology and immunology therefore emerged as explanatory models of sickness and disease that drew in large measure on two distinct yet complementary Cold War horrors" (Ogden, 2000, p. 248). Virologists postulated the existence of powerful viruses capable of violating those borders under favourable circumstances. Immunologists, on the other hand, insisted on the weakening of the immune system due to other factors, such as the repeated use of drugs and a promiscuous sex life.

The most important "dissenters," or denialists, included the virologist Peter H. Duesberg, as well as the Nobel prize winner Kary B. Mullis (1996), who saw the deaths caused by AIDS as being concomitant with a promiscuous sexuality and the use of drugs, both behaviours being a risk for human health and capable of weakening the immune system. Their claims remained isolated voices, but Duesberg's idea is nevertheless because of its criticism of established knowledge. Most scientists thought HIV to be a retrovirus that infected the cell, whilst Duesberg suggested that retroviruses might be mere passengers incapable of causing AIDS and that the cause of the syndrome was ascribable to the use of drugs and sexual practices. Soon, next to these alternative theories, which albeit discussed the sphere of medical research, conspiracy theories began to spread. These did not refute the action of the virus but suggested that the virus was being used as a biological weapon. These new theories about AIDS fell within the wider set of anti-government theories. Some of these theories were accepted by William S. Burroughs, who had described many sexual viruses in his novels. And precisely the initial insistence on the homosexuality-virus link, which was evident even from the first name given to AIDS in 1982-GRID (gay-related immune deficiency)_could not fail to call to mind the B-23 sexual virus invented by the writer.

The effects of the B-23 described by Burroughs are very similar to those produced by Kaposi's sarcoma, the disease most commonly associated with AIDS; but these effects, the red spots and buboes on the skin, were not new in literature. Already in literature, red and associated are linked with death: in the book of dreams by Artemidorus, purple is the colour of death: apart from priests and actors, purple "brings about pitfall and dangers [and exposed secret things], and signified that those who 
are sick will be beg grieved by bitter humours and bring about wounds and, to others, fever" (Harris-McCoy, 2012, p. 157). In American literature perhaps the first author to describe a similar thing was Edgar Allan Poe in his classic "The Mask of the Red Death" (1842). In this story, the author imagines that a disease called red death spreads throughout a village and even manages to penetrate the isolated castle of Prince Prosperous. Poe describes the effect of the virus as follows:

Blood was its Avatar and its seal-the redness and the horror of blood. There were sharp pains, and sudden dizziness, and then profuse bleeding at the pores, with dissolution. The scarlet stains upon the body and especially upon the face of the victim, were the pest ban which shut him out from the aid and from the sympathy of his fellow-men. And the whole seizure, progress and termination of the disease, were the incidents of half an hour. (Poe, 201)

A disease characterized by scarlet red sores is also described by Jack London in the novel The Scarlet Plague (1912). The story takes place after an epidemic dragged the world back to barbarity. Like AIDS in the early days, London's plague had a 100\% mortality rate : "No one ever recovered" (London, 1912, 51), and "From the moment of the first signs of it, a man would be dead in an hour" (ibid, p. 52). In Joseph Millard's The Gods Hate Kansas (1941), red is again central to death: after meteorites fall on a Kansas farm, people develop a sickness that produces a "terrible internal pressure [that] literally blasted every drop of blood in his body out to the surface, turning the puffed flesh a hideous crimson, dotting it with tiny droplets of exuded blood" (Millard, 1941, pp. 33-34). And as with AIDS, there is no sense in the novel of "what it is, where it came from, or how to stop it" (ibid, p. 34). There are, of course, many other outbreak stories, and these anticipate the virus B-23, the scarlet fever, and the red spider fever described by William S. Burroughs, a writer for whom the virus theme is a priority.

All of Burroughs's novels, starting from Naked Lunch (1959), under a superficial science fiction plot, describe a mankind controlled by hidden persuaders who operate through the spread of viruses. The peculiarity of the virus is that it does not kill the body but conditions it to benefit the virus itself without the host realizing that it has been invaded. Some characteristics of Burroughs's viruses have undeniable similarities with HIV. First of all, they are all sexually-transmitted viruses. As regards their diffusion, they seem to develop first in tropical regions and then spread throughout the world. For example, the virus in Naked Lunch

started in Addis Ababa like the Jersey Bounce, but these are modern times, One World. Now the climactic buboes swell up in Shanghai and Esmeraldas, New Orleans and Helsinki, Seattle and Cape Town. But the heart turns home and the disease shows a distinct predilection for Negroes, is in fact the white haired boy of white supremacists. (Burroughs, 1959, p. 36)

But the virus that led some readers to define Burroughs a prophet of AIDS is from two later works written at the end of the 1970s. In the novel Blade Runner: 
a Movie (1979), Burroughs describes an alternative present where birth control in an overpopulated America is achieved through a kind of forced sterilization: only those agreeing to sterilization are allowed access to the Healthcare Service. This makes it possible to control ethnic and social minorities. In such a situation, many doctors practice in secret, an activity that will turn out to be useful the moment in which an epidemic of accelerated cancer breaks out. The only vaccine is the B-23 virus, which causes scarlet fever "with nipples of flesh growing all over him like exotic plants. This is Virus B-23, the virus of biologic mutation" (Burroughs, 1979, n.i). Here too the scarlet wounds are similar to those of Kaposi's sarcoma.

The virus is described in more detail in Cities of the Red Night (1981). It is still the B-23 virus, but here it is not used as a vaccine. One of the three tales that make up the novel is about private investigator Clem Snide, who has to find a missing boy named Jerry. When he finds the boy's body, it is missing the head and is covered with blotches. A friend of the young man, Peter Winkler, also died, and his body was covered with the same red blotches. Whoever was in contact with Jerry seems to have died of scarlet fever. Clem Snide, on the other hands, believes that the disease is an infection caused by a virus. All the characters suffer, to some extent, from the virus B-23: the health official Farnsworth, falls ill while travelling from Waghdas to Ghadis, infected by an unknown virus; the same thing happens to the patrol led by Yen Lee, who discovers a sick person in a village during a reconnaissance mission; the people of the prehistoric cities of the Gobi Desert also suffer. The virus is the result of an experiment conducted by Doctor Pierson, a drug-addict physician who works for a government agency that is fighting a bacteriological war in different eras (in prehistoric Asia, in an unidentified jungle of the 1920s, in the America of the 1970s). Burroughs wrote the story long before 1981 (the year of its publication) but describes a disease with some striking similarities to AIDS. The fictional disease is tied to the world of homosexuals, it is sexually transmissible, it is fatal, and no one had ever seen it before. It was this series of likenesses that led James Grauerholz to say that a virus similar to those described by Burroughs existed indeed, and it was AIDS (Burroughs, 1984).

Ghost of Chance (1991) describes the same virus and defines it as red spider fever. The novel features once again the character of the pirate Captain Mission, already a leading character in one of the stories of Cities of the Red Night. The virus, which manifests itself as different variants, is spread by a red spider. Just a few seconds after being bitten, the subject feels intense itching that burns and spreads throughout the body. The glands swell up and burst open, and the infected person, screaming in agony, has involuntary orgasms, at the same time defecating excrement full of the spider's eggs. In the end, the person dies within $24 \mathrm{~h}$ due to haemorrhaging and choking caused by swelling of the throat and lungs.

Though fascinated by his own literary creations, Burroughs wasted no time in replacing the B-23 virus with the real HIV in his writings. In the novel The Western Lands (1987), the writer revisits Egyptian mythology just as it was described in the novel Ancient Evenings (1983) by Norman Mailer. All human beings have seven souls in conflict one with the other in order to gain control of the person. The main soul that should be in charge is called Ren; Sekem is the operator who executes the command; $\mathrm{Ba}$ represents the feelings, and so on. Burroughs explicitly writes 
that the Ba soul, the one concerned with love and sex "is rotten with AIDS" (Burroughs, $1987 \mathrm{~b}$, p. 6), and that "many Bas have poison juices" (ibid). In this way, he underscores the link between virus and sexuality that during those years was widely demonized and feared.

Burroughs did not immediately participate in the debate about AIDS, as other gay writers did instead - such as Samuel R. Delany, who instantly felt involved and duty bound to launch the alarm on the danger of the transmission (Delany, 1985, 2000). Burroughs did not seem to care about the danger and mortality of the virus; rather, he saw the virus as a method to identify some otherwise unrecognizable groups, and he adopted conspiracy theories about AIDS. So, if Burroughs made a prophecy, it did not so much affect the virus itself but the way in which society related to it, to its inception and outbreak, and to the way in which politics and medical research coped with it.

When the virus started to claim victims, many writers and intellectuals spoke out to indicate how the world of sexual relations was destined to change: for example, novels such as Dorothy Bryant's A Day in San Francisco (1983) and Paul Reed's Facing It: A Novel of AIDS (1984) described the atmosphere of those first years. Samuel R. Delany in 1984: Selected Letters (2000) recorded the alarm of New York gay men. While these authors focused on the facts, Burroughs focused on the possibility that the virus had been artificially created to control the population. In The Four Horsemen of the Apocalypse, Burroughs suggested the use of viruses as an ethnic weapon capable of eliminating one race while leaving another one unscathed (because of enzymes that are able to distinguish friends from enemies at the cellular level). When the theory that the HIV was the cause of AIDS became almost unanimously accepted in the mid-1980s, Burroughs started to make statements on the possibility that the HIV virus had been created in a laboratory. During an interview with Jim McMenamin in 1987 entitled "The Non-Body Route," Burroughs reiterated its beliefs by quoting an article that

claims there is evidence that AIDS could have been a laboratory creation. [...] The Whole AIDS scare is mainly a publicity campaign on the part of Ronald Reagan and that whole Moron Majority lunatic fringe. [...] Certainly, the way in which AIDS is spreading in this country suggest that is was done deliberately - but probably by us, not by Russia. (Burroughs, 1987a, p. 686).

Burroughs said he could not make any definitive claims on the creation of AIDS in a laboratory and could only claim that "it certainly could have been" (ibid, p. 687). He reiterated the position in the interview "Afterlife." The following year, in another interview, Burroughs thought he had found a scientist that, like him, believed HIV to be an artificially created virus - the English physician John Seal. ${ }^{1}$ His belief, Burroughs explains, was that HIV "is biologic warfare by the US Government against

\footnotetext{
${ }^{1}$ Burroughs is probably referring to the article that appeared on the first page of the Sunday Express edition of 26 October 1986 entitled "AIDS Made in Lab Shack."
} 
gays and blacks" (Burroughs, 1988, p. 695). In fact, Burroughs believed that fear of the disease may be convenient for government policies.

Burroughs was principally interested in the "strategic" meaning of the virus, in terms of controlling those population niches that do not comply with the American idea of normality. With a paranoid view of reality, which in any event represented the leitmotiv of his literary works, Burroughs had initially described a sexually-transmitted artificial virus. When some readers thought they saw some sort of prophecy, Burroughs focused on the conspiracy-related aspects that interested him the most, among which, in addition to population control by means of a virus, there was also the topic of the plot hatched by pharmaceutical companies against the population. In the 1960s, he had already reported (in the postscript of Junky) the FDA's failure to acknowledge the apomorphine of Dr. John Yerbury Dent as a method rehab, like methadone. Burroughs's idea was that the apomorphine, by acting on drug addiction like a medicine acts on a disease, is just like a good cop: it does its job and leaves (Burroughs, Odier). But treatments such as methadone are therapies that require commitment and consistence, and the drug addict has to maintain it for a long time. In this way, drug addiction becomes a chronic disease with which many commercial interests can be associated. Moreover, according to Burroughs, methadone consumption through prescription allows the government to know who the drug addicts are and thus to control them.

Burroughs suggested the same mechanism, not applied this time to drug addiction but to an epidemic, in the first episodes of Cities of the Red Night. In these episodes, he describes an attempt by the CIA to control the South American population by spreading a virus to prevent non-white people from expanding their populations to North America. With the onset of AIDS, the writer imaged HIV to be a laboratory product, the spreading of which entailed therapy and so knowledge of the identity of the people who were at highest risk of infection-in other words, gays and drug addicts.

As Burroughs got older, his conspiracy theories became even more paranoid. When Burroughs became interested in the hypothesis that UFOs were real phenomenon in the 1990s, he imagined that the aliens (which he calls Grays) were in cahoots with the government and that HIV had been spread with their support: "AIDS is spread by U.S. agencies who make deals with the Grays, to target 'undesirable:' niggers, spics and queers. [...] Any case, what sort of real dent in overpopulation is AIDS?" (Burroughs, 2000, pp. 81-82). For some critics, Burroughs is less a prophet than an author of a kind of "pre-biography" (Wald, 2008, p. 214) of the HIV virus. One thing is certain: while other authors wrote about viruses, none connect disease with sexuality in the way that Burroughs does- that is, with homosexuality. Critics and journalists highlight how Burroughs describes a virus similar to AIDS (Smith, 2001; Wills, 2016) but not how origins of the virus in risky behaviours in Burroughs's novels call to mind the different opinions about AIDS represented in the Duesberg-Gallo-Montaigner querelle. Susan Sontag wrote that the concept of virus is perfectly suited for being the theme of conspiracy. Viruses are "implacable, insidious, infinitely patient" (Sontag, 1988, p. 154). Viruses are non-complex form of life capable of conveying genetic information, changing cells, and, most importantly, of evolving. Burroughs depicts the virus as a biological weapon in his Nova 
Trilogy, but there it was more of a metaphysical concept rather than a biological weapon. In Blade Runner and Cities of the Red Night, the virus is a real biological vector, a tool to control particular classes of citizens.

Rather than the representation of the disease and its red buboes, Burroughs highlights the intuition ("prediction," if we want to use Regina Weinrich's term) of the virus as a political entity capable of influencing the thought of large groups. The propaganda of the Soldiers of Christ in Blade Runner foreshadows the beliefs of many people in the AIDS-era America. Burroughs, as a gay man, believed himself to belong to one of the minorities controlled by the government, together with drug addicts and African-Americans. ${ }^{2}$ In Cities of the Red Night, the B-23 virus, of prehistoric origin, is spread by the government to bring to the open, and therefore to monitor, some segments of the population.

A study conducted in 1999 indicated that in the United States, 27\% of AfricanAmericans believed that the human immunodeficiency virus was developed by the federal government in order to exterminate the black population, whilst an additional 23\% were undecided. Endorsing AIDS-conspiracy beliefs was not related to age or income but was related to education levels. Blacks who agreed that AIDS is a conspiracy against them tended to be culturally traditional, college-educated men who had experienced considerable racial discrimination (Klonoff and Landrine, 1999). Burroughs's belief that AIDS was a virus created to eliminate undesired minorities was similar to the belief that some African-American groups held, as reported by Judith L. Pastore: "Sadly, many African American are convinced that the AIDS virus was created by whites as part of a deliberate policy of genocide, which also includes channelling drugs into black neighbourhoods and unjustly prosecuting elected black officials" (Pastore, 1993, p. 27). With the explosion of the disease, Burroughs soon became the paranoid prophet of the virus.

Instead of translating in literature his own anxiety by spreading a message of sharing and help, like Delany did, ${ }^{3}$ Burroughs spread his paranoid convictions by inserting himself in field of conspiracy theory. It included those who denied the existence of the virus; those who affirmed the existence of the HIV virus but that it was not the virus that caused AIDS (Duesberg and colleagues); those who believed that HIV caused AIDS and that it had been spread for the purpose of controlling/ eliminating certain ethnic groups or specific groups of the population; those who imagined a disproportionate government budget, strategically allocated. Burroughs belongs to these last two categories: he believed the virus to be a laboratory product and did not believe in governmental research suspecting instead that pharmaceutical companies were the beneficiaries, as in Blade Runner, a Movie.

\footnotetext{
${ }^{2}$ In Blade Runner, Burroughs has the supporters of private healthcare dedicated to government control state: "Here we are, paying to keep the niggers and the spics and the beatniks in hotels and hospitals. We pay for their stinking dope habits, give them money not to work, and what about us? Can we afford to spend $\$ 500$ a day for a hospital bed?" (Burroughs Blade Runner, n.i. [14]).

${ }^{3}$ On the last page of the fantasy novel The Tale of Plague and Carnival, which talks about AIDS in the fantasy version, he gives the address of the Gay Men's Health Crisis of New York so that all readers can obtained true and up-to-date information about the (Delany, 1985, p. 353).
} 
Burroughs always had an anti-academic approach to science and preferred to follow alternative theories and therapies. He denied the effectiveness of recognized medical therapies and affirmed the effectiveness of others. Burroughs was anti-establishment, to be sure. His denials resemble today's denials of Covid19 negationists and anti-vaxxers. We have lessons to learn from Burroughs and his paranoia. Lives depend on learning these lessons.

\section{References}

Beck-Sague, C. M., \& Beck, C. C. (2004). HIV and AIDS. Chelsea House Publishers.

Burroughs, W. S. (1959). Naked lunch-the restored text. Grove Press.

Burroughs, W. S. (1979). Blade runner, a movie. Blue Wind Press.

Burroughs, W. S. (1981). Cities of the red night. Picador.

Burroughs, W. S. (1984). Attack anything moving. In S. Lotringer (Ed.), Burroughs live 1960 (pp. 603-608). Semiotext(e).

Burroughs, W. S. (1985). Queer. In S. Lotringer (Ed.), Burroughs live 1960 (pp. 613-619). Semiotext(e).

Burroughs, W. S. (1987a). The non-body route. In S. Lotringer (Ed.), Burroughs live 1960 (pp. 670690). Semiotext(e).

Burroughs, W. S. (1987b). The western lands. Penguin Books.

Burroughs, W. S. (1988). An explosion of color. In S. Lotringer (Ed.), Burroughs live 1960 (pp. 691701). Semiotext(e).

Burroughs, W. S. (1989). A thanksgiving prayer. In W. S. Burroughs (Ed.), Tornado alley (pp. 3-8). Cherry Valley Editions.

Burroughs, W. S. (1991). Ghost of chance. Serpent's Tail.

Burroughs, W. S. (2000). Last words. Grove Press.

Burroughs, W. S., \& Odier, D. (1969). The job. Penguin Books.

Delany, S. R. (1985). Flight from Nevèrÿon. Bantam Books.

Delany, S. R. (2000). Selected letters. Voyant Publishing.

Duesberg, P. H. (1996). Inventing the AIDS virus. Regnery Publishing.

Gilman, S. L. (1988). Disease and representation: Images of illnes from madness to AIDS. Cornell University Press.

Hahn, B. H., \& Sharp, P. M. (2011). Origins of HIV and the AIDS pandemic. Cold Spring Harbor Perspectives in Medicine, 1(1), a006841. https://doi.org/10.1101/cshperspect.a006841

Harris-McCoy, D. E. (2012). Artemidours's oneirocritica: Text, translation, and commentary. Oxford University Press.

Klonoff, E. A., \& Landrine, H. (1999). Do blacks believe that HIV/AIDS is a government conspiracy against them? Preventive Medicine, 28(5), 451-457.

Kurth, R. (1990). Does HIV cause AIDS? An updated response to Duesberg's theories. Intervirology, 31(6), 301-314.

London, J. (1912). The scarlet plague. Mills \& Boon.

Millard, J. (1941). The gods hate Kansas. Startling Stories, 6(3), 16-86.

Mullis, K. B. (1996). Foreword. In P. H. Duesberg (Ed.), Inventing the AIDS virus (pp. xi-xiv). Regnery Publishing.

Ogden, D. (2000). Cold War science and the body politic: An immuno/virological approach to angels in America. Literature and Medicine, 19(2), 241-261.

Pastore, J. L. (1993). What are the responsibilities of representing AIDS. In J. L. Pastore (Ed.), Confronting AIDS through literature (pp. 15-35). University of Illinois Press.

Poe, E. A. (1842). The mask of the red death. In E. A. Poe (Ed.), Tales of mistery and imagination (pp. 201-206). J. M. Dent \& Sons.

Smith, D. (2001). Beat currencies. Remembering the dangers of being on the road. Austin Chronicle Aug. 3, 2001. https://www.austinchronicle.com/books/2001-08-03/82507/

Sontag, S. (1988). AIDS and its metaphor. Penguin Books. 
Wald, P. (2008). Contagious: Cultures, carriers, and the outbreak narrative. Duke University Press.

Wills, D. S. (2016). Prophecy in Naked lunch. Beatdom. Retrieved from 14 May 2021 https://www.beatd om.com/prophecy-naked-lunch/\#: :text=Naked\%20Lunch\%20is\%20the\%20book,\%2C\%20eventual $1 \mathrm{y} \% 2 \mathrm{C} \% 20$ respected $\% 20$ postmodernist $\% 20$ writer.

Publisher's Note Springer Nature remains neutral with regard to jurisdictional claims in published maps and institutional affiliations. 